\title{
Seminal characteristics and sensitivity of Astyanax lacustris (Characiformes: Characidae) sperm to cryoprotective solutions based on dimethylsufoxide and methylglicol
}

Correspondence:

Alexandre Ninhaus-Silveira alexandre.ninhaus@unesp.br
Submitted May 22, 2020

Accepted August 6, 2020

by Bernardo Baldisserotto

Epub October 09, 2020

Online version ISSN 1982-0224

Print version ISSN 1679-6225

Neotrop. Ichthyol.

vol. 18, no. 3, Maringá 2020
${ }^{\oplus}$ Laicia Carneiro-Leite ${ }^{1},{ }^{\oplus}$ Cristiane Bashiyo-Silva ${ }^{2}$,

${ }^{\circ}$ Yasmim Alves Araújo Oliveira ${ }^{3},{ }^{\circ}$ Laís Pedroso Borges ${ }^{1}$,

${ }^{\circledR}$ Malbelys Padilla Sanchez ${ }^{1},{ }^{\oplus}$ Luciane Gomes da Silva ${ }^{1}$,

${ }^{(1)}$ Stella Indira Rocha Lobato ${ }^{1}$, ${ }^{-}$Flávia Cristina Rodrigues-Lisoni",

${ }^{(D)}$ Rosicleire Veríssimo-Silveira ${ }^{5}$ and ${ }^{\mathbb{C}}$ Alexandre Ninhaus-Silveira ${ }^{5}$

This study aimed to determine the semen characteristics of Astyanax lacustris after hormonal induction and to evaluate the sensitivity of the species sperm to cryoprotective solutions based on the cryoprotectants dimethyl sulfoxide and methyl glycol. Volume, color, sperm concentration, total motility and aspects of sperm movement were analyzed using "Integrated Semen Analysis System". Three different extenders were tested: A) glucose $5 \%+$ egg yolk $10 \%$, B) BTS $^{\circledR} 5 \%$ and C) glucose $5 \%$ and two permeable cryoprotectants: dimethyl sulfoxide $\left(\mathrm{Me}_{2} \mathrm{SO}\right)$ and methyl glycol (MTG). Fresh $A$. lacustris semen presented total motility of $76.6 \pm 11.2 \%$, motility duration of $33.0 \pm 2.2 \mathrm{~s}$, sperm concentration of $7.22 \pm 3.2 \times 10^{9} \mathrm{sptz} / \mathrm{mL}$ and seminal osmolality of $219 \pm 0.03 \mathrm{mOsm} /$ $\mathrm{kg}^{-1}$. The toxicity test showed the highest total motility values at the MTG15\%+A, $\mathrm{Me}_{2} \mathrm{SO} 15 \%+\mathrm{B}$ and $\mathrm{Me}_{2} \mathrm{SO} 10 \%+\mathrm{C}$ dilutions, and the $\mathrm{Me}_{2} \mathrm{SO} 10 \%+\mathrm{C}$ and $\mathrm{Me}_{2} \mathrm{SO} 15 \%+\mathrm{C}$ dilutions presented the highest values for curvilinear velocity, linear velocity and average velocity. The tested protocol was not effective at maintaining the viability of $A$. lacustris semen after freezing because no motility was observed in any of the dilutions. However, the Comet Assay demonstrated that cryoprotectant solutions were effective in protecting the genetic material of cells, as DNA damage levels were low, with no difference between control and $\mathrm{Me}_{2} \mathrm{SO} 10 \%+\mathrm{A}$, dilutions $\mathrm{MTG} 10 \%+\mathrm{C}, \mathrm{Me}_{2} \mathrm{SO} 10 \%+\mathrm{B}$ and $\mathrm{Me}_{2} \mathrm{SO} 15 \%+\mathrm{B}$.

Keywords: Characiformes, DNA integrity, Freezing, Semen quality, Yellow-tailed Lambari.

1 Pós-graduação em Ciências Biológicas: Zoologia, Instituto de Biociências, Universidade Estadual Paulista "Júlio de Mesquita Filho" (UNESP), Av. Rubião Jr, s/n, 18618-970 Botucatu, SP, Brazil. (LCL) laicialeite@hotmail.com; (LPB) lais_borges27@hotmail.com; (MPS) malbelys.padilla@unesp.br; (LGS) luciane.gomess@outlook.com.br; (SIRL) stellaindira1@hotmail.com.

2 Instituto Federal de Educação, Ciência e Tecnologia do Sul de Minas Gerais, Estrada de Muzambinho, km 35, Muzambinho, 37890-000 Minas Gerais, Brazil. (CBS) cristianebashiyo@gmail.com.

3 Pós-graduação em Ciência e Tecnologia Animal, Universidade Estadual Paulista "Júlio de Mesquita Filho” (UNESP), Av. Brasil, 56, 15385-000 Ilha Solteira, SP, Brazil. (YAAO) yasmim.bio.oliveira@gmail.com.

4 Laboratório de Genética Molecular, Departamento de Biologia e Zootecnia, Faculdade de Engenharia, Universidade Estadual Paulista "Júlio de Mesquita Filho", Av. Brasil, 56, 15085-000 Ilha Solteira, SP, Brazil. (FCRL) flavia.lisoni@unesp.br.

5 Laboratório de Ictiologia Neotropical (L.I.NEO), Departamento de Biologia e Zootecnia, Faculdade de Engenharia, Universidade Estadual Paulista "Júlio de Mesquita Filho", Av. Brasil, 56, 15085-000 Ilha Solteira, SP, Brazil. (ANS) alexandre.ninhaus@unesp.br, (corresponding author); (RVS) rosicleire.verissimo@unesp.br. 
O objetivo deste estudo foi determinar as características do sêmen de Astyanax lacustris após indução hormonal e avaliar a sensibilidade dos espermatozoides da espécie a soluções crioprotetoras baseadas nos crioprotetores dimetilsulfóxido e metilglicol. Volume, cor, concentração espermática, motilidade total e aspectos do movimento espermático foram analisados usando o "Sistema Integrado de Análise de Sêmen (ISAS ${ }^{\circledR}$ CASA)". Três extensores diferentes foram testados: A) glicose $5 \%+$ gema de ovo $10 \%$, B) BTS ${ }^{\circledR} 5 \%$ e C) glicose $5 \%$ e dois crioprotetores permeáveis: dimetilsulfóxido $\left(\mathrm{Me}_{2} \mathrm{SO}\right)$ e metilglicol (MTG). O sêmen fresco de $A$. lacustris apresentou motilidade total $76,6 \pm 11,2 \%$, duração da motilidade $33,0 \pm 2,2$ s, concentração de espermatozoides $7,22 \pm 3,2 \times 10^{9} \mathrm{sptz} / \mathrm{mL}$ e osmolalidade seminal $219 \pm 0,03 \mathrm{mOsm} / \mathrm{kg}^{-1}$. O teste de toxicidade apresentou maiores valores de motilidade total nas diluições MTG15\%+A, $\mathrm{Me}_{2} \mathrm{SO} 15 \%+\mathrm{B}$ e $\mathrm{Me}_{2} \mathrm{SO} 10 \%+\mathrm{C}$, e as diluições $\mathrm{Me}_{2} \mathrm{SO} 10 \%+\mathrm{C}$ e $\mathrm{Me}_{2} \mathrm{SO} 15 \%+\mathrm{C}$ apresentaram maiores valores de velocidade curvilínea, velocidade linear e velocidade média. O protocolo testado não foi eficaz em manter a viabilidade do sêmen de A. lacustris póscongelamento, pois não foi observada motilidade em nenhuma das diluições. No entanto, o Ensaio Cometa demonstrou que as soluções crioprotetoras eram eficazes na proteção do material genético das células, pois os níveis de dano ao DNA eram baixos, sem diferença entre controle e $\mathrm{Me}_{2} \mathrm{SO} 10 \%+\mathrm{A}$, MTG10\%+C, $\mathrm{Me}_{2} \mathrm{SO} 10 \%+\mathrm{B}$ e $\mathrm{Me}_{2} \mathrm{SO} 15 \%+\mathrm{B}$.

Palavras-chave: Characiformes, Congelamento, Integridade do DNA, Lambarido-rabo-amarelo, Qualidade do sêmen.

\section{INTRODUCTION}

The yellow-tailed lambari Astyanax lacustris (Lütken, 1875) (= Astyanax altiparanae), belonging to the Characidae family, is a small species native to the upper Paraná basin, with omnivorous eating habit, easy environmental adaptation, rapid growth and spawn more than once a year, so it is used as a biological model (Sabbag et al., 2011; Gonçalves et al., 2012a,b; Lucena, Soares, 2016). With great economic potential, this species can be used as a sport bait, as well as being well accepted as a snack, which is why production is growing in aquaculture (Gonçalves et al., 2012a).

Considering their biological and economic importance, the development of technologies that catalyze the reproductive process of captive species is necessary, in order to support the projects of environmental preservation and commercial production. Technologies such as methods for the cryopreservation of fish sperm have the objective of facilitating and maximizing the reproduction of species of commercial interest, either threatened or endangered, and favoring the processes of genetic improvement in these situations (Cárton-Garcia et al., 2013). However, the freezing and thawing processes can cause decreased sperm motility, loss of functional and structural integrity of the plasma membrane, morphological changes in gametes and changes in sperm fertilization capacity (Streit Jr. et al., 2006; Viveiros et al., 2009; Ciereszko et al., 2014; Viveiros et al., 2015; Yang et al., 2016; Galo et al., 2019). 
Due to the problems mentioned above, cryoprotective substances are added to the semen, whose main functions are to decrease the freezing point of the cell and protect the cell membrane during the cryopreservation process (Maria et al., 2006).

The cryoprotectants used can be divided into two groups: impermeable (glucose, sucrose, etc), composed of large molecules and permeable ones, formed by chemical substances composed of small molecules, highlighting some types already used in semen conservation protocols of freshwater fish, such as dimethyl sulfoxide $\left(\mathrm{Me}_{2} \mathrm{SO}\right)$ (Brycon amazonicus (Agassiz, 1829) (Ninhaus-Silveira et al., 2006a); Colossoma macropomum (Cuvier, 1816) (Carneiro et al., 2012); Brycon orbignyanus (Valenciennes, 1850) (Chiacchio et al., 2017)); and methyl glycol (Brycon opalinus (Cuvier, 1819) (Viveiros et al., 2012); Prochilodus lineatus (Valenciennes, 1837) (Viveiros et al., 2010)), this cryoprotectant being considered as the most effective in the cryopreservation of fish semen (Elliott et al., 2017). Viveiros et al. (2012) also highlighted that the use of methyl glycol as a cryoprotectant for neotropical fish semen is growing in Brazil.

To develop a cryoprotectant solution that maintains the seminal characteristics and fertilization capacity of the sperm species, it is necessary to evaluate the tolerance of sperm cells to exposure to different cryoprotectant substances, so that there is effective sperm protection during the cryogenic process, since this tolerance varies according to the species of fish used (Judycka et al., 2018; Pereira et al., 2019).

Based on the assumptions that there is no concrete scientific information about seminal characteristics of Astyanax lacustris and no effective cryopreservation protocol has been established for semen of the species, this work aimed to determine the characteristics of $A$. lacustris semen after hormonal induction, and to evaluate the sensitivity of the species' sperm to cryoprotectant solutions based on dimethyl sulfoxide and methyl glycol cryoprotectants, in order to contribute to the development of a cryopreservation protocol for semen of this species.

\section{MATERIAL AND METHODS}

Animals and obtaining gametes. Thirty-eight sexually mature specimens were used of Astyanax lacustris, with a total mean length of $10.4 \pm 0.5 \mathrm{~cm}$, a standard length of $8.6 \pm$ $0.5 \mathrm{~cm}$ and an average mass of $16 \pm 3.1$ grams, belonging to the Laboratório de Ictiologia Neotropical (L.I.NEO), Universidade Estadual Paulista "Júlio de Mesquita Filho", Ilha Solteira Campus. The fish were kept in 4,500L circular PVC tanks, at a ratio of 2:1 (male/ female), with an average temperature of $27.7^{\circ} \mathrm{C}, \mathrm{pH} 7.6$ and ammonia of $0.00 \mathrm{ppm}$.

Astyanax lacustris males were hormonally induced using single-dose Ovopel ${ }^{\circledR}(\mathrm{GnRh}$ - analogue + Dopamine) (3 mg/kg live fish) (Yasui et al., 2015). After 226 hours/degrees, the fish were anesthetized with benzocaine solution (Sigma-Aldrich E1501) (100mg/L), and semen was collected by craniocaudal abdominal massage of the body, with the aid of 10-100 $\mu$ l micropipettes (Kasvi-K1-100B). Contamination with blood or feces was carefully avoided.

Determination of fresh sperm characteristics. Thirty-eight males were used to determine sperm characteristics. Staining was visually estimated considering the translucent and white patterns and the ejaculated volume measured by micropipettes. 
To determine seminal plasma osmolarity, semen was centrifuged at 3,000 rpm for 15 minutes, and the supernatant was collected and analyzed using an osmometer (OSMOMAT ${ }^{\circledR}$ model 030, Berlin, Germany). Sperm concentration (sperm/mL) was measured using the Neubauer hematimetric chamber. For this, semen was diluted in formalin-saline solution at a ratio of 1:1000 (Bashiyo-Silva, 2014). Sperm motility characteristics were evaluated using the CASA (Computer Assisted Sperm Analysis) system (ISAS ${ }^{\circledR}$ Integrated Semen Analysis System, Proiser, Valencia, Spain) coupled to a phase contrast microscope UB200i (UOP/Proiser) with a 10x negative phase contrast objective. The images were captured with ISAS 782C camera (Proiser, Spain) and processed with CASA software, recorded at 25 image per seconds (fps). Sperm activation was performed by adding $30 \mu \mathrm{l}$ of distilled water to $0.5 \mu \mathrm{l}$ of semen using a Makler TM camera (Sefi Medical Instruments Ltd, Israel), and after the analyzes were performed every 10 seconds. Total motility (MOT, \%), progressive motility (PRG, \%), porcentagem fast sperm $(\mathrm{VAP}=50-100 \mu \mathrm{m} / \mathrm{s})$, medium $(\mathrm{VAP}=25-50 \mu \mathrm{m} / \mathrm{s})$ and slow $(\mathrm{VAP}=10-25 \mu \mathrm{m} / \mathrm{s})$, curvilinear velocity $(\mathrm{VCL}, \mu \mathrm{m} / \mathrm{s})$, linear velocity $(\mathrm{VSL}, \mu \mathrm{m} / \mathrm{s})$, and mean velocity (VAP, $\mu \mathrm{m})$, the linearity coefficient (LIN, \%), the rectilinearity coefficient (STR, \%), the average oscillation of the sperm spatial trajectory (WOB, \%), the lateral displacement amplitude of the head (ALH, $\mu \mathrm{m})$ and the beat cross frequency (BCF, $\mathrm{Hz}$ ) were also evaluated. Straightness percentage (STR) $>80 \%$ was used for sperm to be considered progressive. Sperm with VCL $<10 \mu \mathrm{m} / \mathrm{s}$ were considered immovable.

Cryoprotectant toxicity test. Two internal cryoprotectants were tested, dimethyl sulfoxide $\left(\mathrm{Me}_{2} \mathrm{SO}\right)$ and methyl glycol (MTG) (Sigma-Aldrich), at concentrations of 10 and $15 \%$, in combination with three diluent solutions: A) composed of $5 \%$ glucose + $10 \%$ egg yolk; B) consisting of 5\% Bestlvile Thawing Solution - BTS ${ }^{\circledR}$ (composition: 79.9\% glucose, $12.71 \%$ sodium citrate, $2.65 \%$ EDTA, 2.65\% sodium bicarbonate and potassium chloride $1.59 \%$, gentamicin sulfate $0.5 \%$ ) (Minitub, Tiefenbach, Germany), and C) composed of only $5 \%$ glucose, thus resulting in twelve treatments, in addition to the control group (fresh semen). Before the toxicity test, the osmolality of solutions $\mathrm{A}, \mathrm{B}$ and $\mathrm{C}$ and the twelve treatments were measured (Tab. 1).

TABLE 1 I Composition of the treatments used for the toxicity test.

\begin{tabular}{|c|c|}
\hline Treatments & Composition \\
\hline $\mathrm{T} 1$ & Egg yolk $10 \%+$ Glucose $5 \%+\mathrm{Me}_{2} \mathrm{SO} 10 \%$ \\
\hline $\mathrm{T} 2$ & Egg yolk $10 \%+$ Glucose $5 \%+\mathrm{Me}_{2} \mathrm{SO} 15 \%$ \\
\hline T3 & Egg yolk 10\% + Glucose 5\% + MTG 10\% \\
\hline $\mathrm{T} 4$ & Egg yolk 10\% + Glucose 5\% + MTG 15\% \\
\hline T5 & $\mathrm{BTS}^{\circledast} 5 \%+\mathrm{Me}_{2} \mathrm{SO} 10 \%$ \\
\hline $\mathrm{T} 6$ & $\mathrm{BTS}^{\circledast} 5 \%+\mathrm{Me}_{2} \mathrm{SO} 15 \%$ \\
\hline $\mathrm{T} 7$ & Glucose $5 \%+\mathrm{Me}_{2} \mathrm{SO} 10 \%$ \\
\hline T8 & Glucose $5 \%+\mathrm{Me}_{2} \mathrm{SO} 15 \%$ \\
\hline T9 & $\mathrm{BTS}^{\oplus} 5 \%+$ MTG $10 \%$ \\
\hline T10 & BTS $^{\circledast} 5 \%+$ MTG $15 \%$ \\
\hline T11 & Glucose 5\% + MTG 10\% \\
\hline T12 & Glucose 5\% + MTG 15\% \\
\hline
\end{tabular}


Semen was diluted 1:25 (semen/cryoprotectant solution) in all treatments and, after 15 minutes (equilibration time), $1 \mu 1$ of diluted semen was placed in a Makler chamber, activated with distilled water and analyzed using the sperm analysis program (ISAS ${ }^{\circledR}$, CASA). All motility parameters mentioned in item 2.4 were measured using four repetitions (fish) for each treatment.

Freezing. For freezing, semen was diluted 1:25 (semen: solution) in eight cryoprotectant solutions selected in the toxicity test (Zanandrea et al., 2016). This dilution was used due to the low amount of semen of the species, approximately $30 \mu 1$. It was then placed into $0.25 \mathrm{~mL}$ plastic straws (Minitub) at room temperature $\left(28^{\circ} \mathrm{C}\right)$; after a 15 minute equilibration period, the straws (8) were placed on a steel mesh tray about 1 $\mathrm{cm}$ away from the surface of liquid nitrogen (Ninhaus-Silveira et al., 2006a) contained in a 33 liter Styrofoam insulating box for seven minutes until reaching a temperature of $-70^{\circ} \mathrm{C}$ (Thermocouple - OMEGA ${ }^{\circledR}$ RDXL4SD) (Viveiros et al., 2000). Subsequently, the samples were immersed in liquid nitrogen and transferred to a cryogenic liquid container (ABS - Pecplan, model ABS20 - MVE). After one month, the samples were thawed in a water bath at $36^{\circ} \mathrm{C}$ for seven seconds (Ninhaus-Silveira et al., 2006b), and motility was checked using the integrated system (ISAS ${ }^{\circledR} \mathrm{CASA}$ ). Four fish (repetitions) were also used per treatment.

DNA damage assessment. The Comet Assay methodology for determining the DNA integrity of cryopreserved sperm was based on the protocol proposed by Singh et al. (1988) and Klaude et al. (1996), and analyzed three repetitions (fish) by treatments. To perform the analyses, histological glass slides were prepared with a thin layer of normal melting agarose (NMP). Next, $10 \mu \mathrm{l}$ of diluted semen and $120 \mu \mathrm{l}$ of low melting temperature agarose (LMP) were added to a microtube. These samples were placed on slides previously prepared with normal agarose, covered with a coverslip and refrigerated for about 30 minutes to solidify. After this time, the slides were immersed in $\mathrm{pH} 10$ lysis solution $\left(2.5 \mathrm{M} \mathrm{NaCl}, 100 \mathrm{mM}\right.$ EDTA, $10 \mathrm{mM}$ Tris, $35 \mathrm{mM}$ Lauril) for one hour at $4{ }^{\circ} \mathrm{C}$.

Subsequently, the slides were placed in an electrophoresis vat that was filled with $\mathrm{pH} 13$ solution (200mM EDTA, $10 \mathrm{~N} \mathrm{NaOH})$, and kept for 30 minutes at $4^{\circ} \mathrm{C}$. Then, the electrophoresis process was performed for a period of 20 minutes at $25 \mathrm{~V} / 300 \mathrm{~mA}$. After this process, the slides were covered with $\mathrm{pH} 7.5$ neutralization solution $(0.4 \mathrm{M}$ Tris) for five minutes (3x), fixed by immersion in ice-cold absolute ethanol for five minutes, and dried at room temperature. To visualize the comet, the slides were stained by adding $100 \mu \mathrm{l}$ of ethidium bromide solution onto each slide, covered with coverslips and analyzed in a 40x objective with the aid of a fluorescence microscope (Olympus, BX-FLA, Japan). In total, 100 cells per sample were analyzed and grouped into damage class according to tail size and intensity as follows: class 0 - no apparent damage, and class 1 to 3 - increasing DNA damage, related to tail length and intensity (Kobayashi et al., 1995) (Fig. 1).

The damage index (total DI) was obtained by multiplying the number of comets in each class by the denominator digit of each class, according to the formula below, where " $n$ " represents the number of cells in each damage class:

$$
\text { DI total }=0 \times(\mathrm{n} \text { Class } 0)+1 \times(\mathrm{n} \text { Class } 1)+2 \times(\mathrm{n} \text { Class } 2)+3 \times(\mathrm{n} \text { Class } 3)
$$




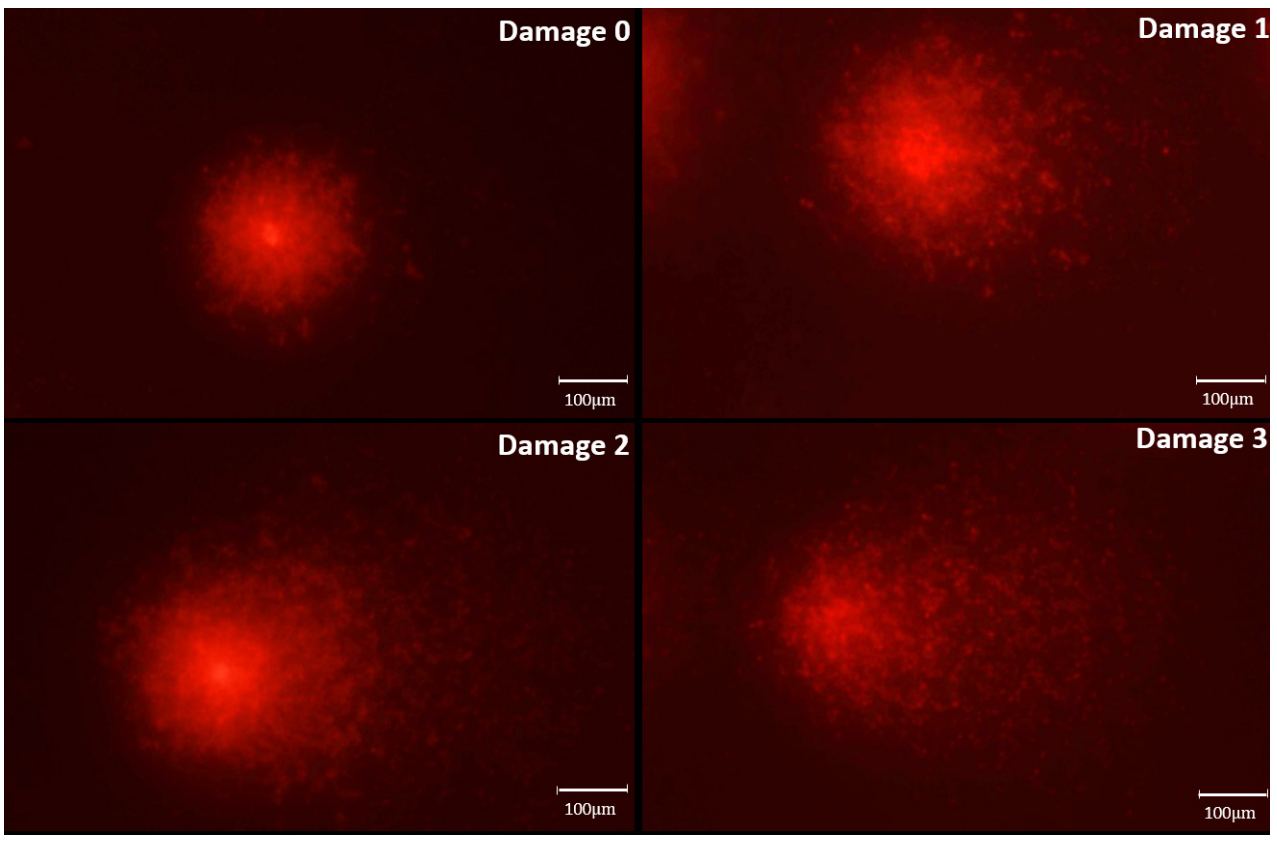

FIGURE 1 I Fluorescence photomicrograph of Astyanax lacustris (100X magnification) of nuclei with different types of damage assessed by the Comet Assay: damage 0 - no apparent damage; damage 1 - little damage; damage 2 - average damage; damage 3 - major damage.

Statistics. Statistical analysis was performed following the subdivided parcel model by analysis of variance (ANOVA). For results showing a significant difference $(\mathrm{p}<0.05)$, the Scott-Knott test was applied to compare control and treatments, and verify the difference between treatments. For nonparametric data, the Kruskal-Wallis test was applied $(\mathrm{p}<0.05)$. Data were analyzed using the R Studio statistical program (RStudio Team ,2015).. The fish was considered as the repetition with five fish per treatment.

\section{RESULTS}

Features of Fresh Semen. Fresh semen was translucent, with little viscous consistency and a seminal volume of about $30 \mu \mathrm{L}$. The parameters for osmolality, sperm motility and concentration for Astyanax lacustris semen are presented in Tab. 2.

Cryoprotectant toxicity test. All solutions used in the toxicity test were hyperosmotic to the seminal plasma of the species (Tab. 3). Despite this, diluent solutions A, B and C without the addition of cryoprotectants activated sperm. And treatments composed of $5 \%$ BTS + 10\% methyl glycol (T9), 5\% BTS + 15\% methyl glycol (T10), 5\% glucose $+10 \%$ methyl glycol (T11) and 5\% glucose $+15 \%$ methyl glycol were toxic for $A$. lacustris semen because, after dilution, no sperm motility was observed.

The total motility (MOT) differed statistically between the control and treatment groups, but no statistically significant differences were observed in the comparison between treatments. Treatments T4, T6 and T7 were the ones that provided higher 
TABLE 2 I Seminal characteristics of fresh Astyanax lacustris semen after hormonal induction.

\begin{tabular}{|c|c|}
\hline Parameters & Fresh semen \\
\hline Sperm concentration $\left(\times 10^{9}\right.$ spermatozoa ml $\left.{ }^{-1}\right)$ & $7.22 \pm 3.2$ \\
\hline Seminal plasma osmolality (mOsm kg-1) & $219 \pm 0.03$ \\
\hline Total motility (\%) & $76.6 \pm 11.2$ \\
\hline Progressive motility (\%) & $55.3 \pm 10.8$ \\
\hline Fast spermatozoa (\%) & $46.0 \pm 22.7$ \\
\hline Medium spermatozoa (\%) & $24.7 \pm 15.3$ \\
\hline Slow spermatozoa (\%) & $5.8 \pm 4.1$ \\
\hline Duration of motility (sec.) & $33.0 \pm 2.2$ \\
\hline Curvilinear velocity $\left(\mu \mathrm{m} \mathrm{s}^{-1}\right)$ & $51.1 \pm 13.6$ \\
\hline Straight line velocity $\left(\mu \mathrm{m} \mathrm{s}^{-1}\right)$ & $41.4 \pm 11.9$ \\
\hline Average path velocity $\left(\mu \mathrm{m} \mathrm{s}^{-1}\right)$ & $48.2 \pm 13.5$ \\
\hline Linearity (\%) & $80.7 \pm 6.7$ \\
\hline Straightness (\%) & $85.9 \pm 4.5$ \\
\hline Wobble (\%) & $93.8 \pm 3.5$ \\
\hline Amplitude of lateral head displacement $(\mu \mathrm{m})$ & $1.1 \pm 0.1$ \\
\hline Beat cross frequency (Hz) & $7.0 \pm 0.3$ \\
\hline
\end{tabular}

TABLE 3 I Osmolality of the solutions used in the toxicity test.

\begin{tabular}{|c|c|c|}
\hline Solution & Composition & Osmolality (mOsm/kg) \\
\hline A & Egg yolk 10\% + Glucose 5\% & 339 \\
\hline B & $\mathrm{BTS}^{\circledR} 5 \%$ & 347 \\
\hline C & Glucose 5\% & 318 \\
\hline $\mathrm{T} 1$ & Egg yolk + Glucose $+\mathrm{Me}_{2} \mathrm{SO} 10 \%$ & 2.766 \\
\hline $\mathrm{T} 2$ & Egg yolk + Glucose $+\mathrm{Me}_{2} \mathrm{SO} 15 \%$ & 3.125 \\
\hline $\mathrm{T} 3$ & Egg yolk + Glucose + MTG 10\% & 2.531 \\
\hline $\mathrm{T} 4$ & Egg yolk + Glucose + MTG 15\% & 2.920 \\
\hline T5 & $\mathrm{BTS}^{\circledast} 5 \%+\mathrm{Me}_{2} \mathrm{SO} 10 \%$ & 2.529 \\
\hline $\mathrm{T} 6$ & $\mathrm{BTS}^{\circledast} 5 \%+\mathrm{Me}_{2} \mathrm{SO} 15 \%$ & 3.056 \\
\hline $\mathrm{T} 7$ & Glucose $5 \%+\mathrm{Me}_{2} \mathrm{SO} 10 \%$ & 2.226 \\
\hline $\mathrm{T} 8$ & Glucose $5 \%+\mathrm{Me}_{2} \mathrm{SO} 15 \%$ & 3.028 \\
\hline T9 & $\mathrm{BTS}^{\circledast} 5 \%+$ MTG $10 \%$ & 2.343 \\
\hline T10 & $\mathrm{BTS}^{\circledast} 5 \%+$ MTG $15 \%$ & 2.843 \\
\hline T11 & Glucose 5\% + MTG 10\% & 2.164 \\
\hline $\mathrm{T} 12$ & Glucose 5\% + MTG 15\% & 2.754 \\
\hline
\end{tabular}

values of total motility (Fig. 2A). Regarding progressive motility (PRG), the highest values were obtained in treatments T7, T8 and T6, respectively; however, there was no statistical difference between them (Fig. 2A).

Regarding the percentage of fast, medium and slow sperm, there was a marked decrease in fast sperm and an increase in medium and slow sperm after dilution in cryoprotective solutions (Tab. 4). However, no statistical difference was observed 
between the control and treatments T7, T8, T1, T2 and T5 for fast sperm, but treatment $\mathrm{T} 7 \mathrm{had}$ the highest number of fast spermatozoids, highlighting that treatments T3, T4 and T6 had less than 10\% of fast spermatozoa differing statistically from the control. In the average sperm there was no difference between any of the treatments, but there was an increase in the percentage of average sperm compared to the control in all treatments with the exception of T7 and T8. The same pattern was observed for slow sperm that significantly increased in relation to the control, with the highest percentage found in the $\mathrm{T} 3$ treatment that differed statistically from the control (Tab. 4).



FIGURE 2 I Comparative analysis of sperm motility of Astyanax lacustris. Total and progressive motility (A), curvilinear velocity (B), straight line velocity (C) and average path velocity (D). Different letters indicate significant differences $(\mathrm{p}<0.05)$ by the Scott-Knott test: Upper case relationship between control and treatments; tiny relationship between treatments.

TABLE 4 I Percentage of fast, medium and slow sperm of Astyanax lacustris in relation to total motility.

\begin{tabular}{|c|c|c|c|c|}
\hline Treatments & Motility (\%) & Fast (\%) & Medium (\%) & Slow (\%) \\
\hline Fresh sperm & $76.6 \pm 11.2$ & $46.0 \pm 22.7^{\mathrm{a}}$ & $24.7 \pm 14,7$ & $5.8^{\mathbf{9}}+1^{\mathrm{b}}$ \\
\hline T1 & $54.2 \pm 16.9$ & $16.1 \pm 7.7^{\mathrm{ab}}$ & $27.0 \pm 8.2$ & $10.9 \pm 3.5^{\mathrm{ab}}$ \\
\hline T2 & $49.6 \pm 6.0$ & $10.2 \pm 1.6^{\mathrm{abc}}$ & $25.3 \pm 3.2$ & $14.1 \pm 2.5^{\mathrm{ab}}$ \\
\hline T3 & $55.4 \pm 7.1$ & $5.0 \pm 4.5^{\mathrm{bc}}$ & $28.0 \pm 7.4$ & $22.3 \pm 11.3^{\mathrm{a}}$ \\
\hline T4 & $61.7 \pm 4.6$ & $5.8 \pm 4.1^{\mathrm{bc}}$ & $38.15 \pm 6.8$ & $17.8 \pm 2.2^{\mathrm{ab}}$ \\
\hline T5 & $52.3 \pm 19.5$ & $10.0 \pm 9.1^{\mathrm{abc}}$ & $26.9 \pm 13.8$ & $15.2 \pm 7.3^{\mathrm{ab}}$ \\
\hline T6 & $59.4 \pm 12.7$ & $3.6 \pm 3.6^{\mathrm{c}}$ & $33.6 \pm 10.1$ & $22.0 \pm 3.0^{\mathrm{ab}}$ \\
\hline T7 & $68.9 \pm 14.8$ & $34.0 \pm 27.5^{\mathrm{a}}$ & $23.1 \pm 5.4$ & $11.8 \pm 9.9^{\mathrm{ab}}$ \\
\hline
\end{tabular}


For the VCL, VSL and VAP parameters, a significant difference was found between the control and treatment groups (Figs. 2B-D). Regarding VCL, treatments T7, T8 and $\mathrm{T} 1$ presented the highest values, but did not differ statistically from the other treatments (Fig. 2B). For VSL and VAP, T7 and T8 represented the treatments with higher velocities, being statistically different from the others. The lowest velocities for both VSL and VAP were obtained at T3 and T4 (Figs. 2C-D).

For LIN and STR, there was only a statistical difference between treatments, with no difference between control and treatment groups, while for WOB there was a statistical difference in the control-treatment comparison and between treatments. For these three parameters, T5, T6, T7 and T8 presented the highest values, differing significantly $(\mathrm{p}<0.05)$ from the other treatments; it can also be shown that T4 was the treatment that provided the lowest values (Figs. 3A-C). An increase of LIN values was also observed for treatments T6, T7 and T8 in relation to the control. This increase was also found for STR in treatments T5, T6, T7 and T8, but only in treatment T7 for WOB.

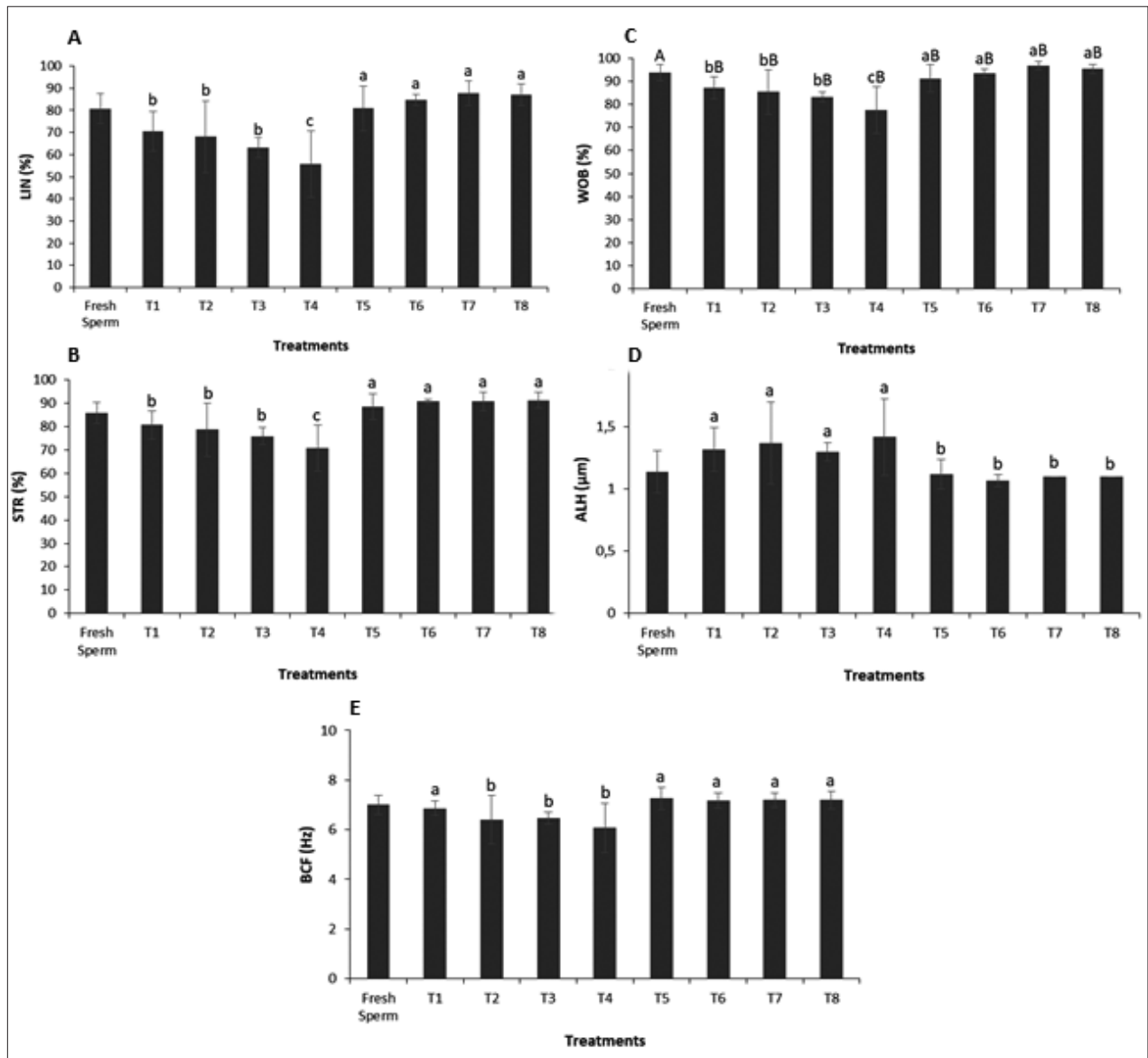

FIGURE 3 । Linearity (A), Rectilinearity (B), Oscillation (C), Head lateral displacement amplitude (D) and beat cross frequency (E). Different letters indicate significant differences $(p<0.05)$ by the Scott-Knott test: Upper case relationship between control and treatments; tiny relationship between treatments. 
Regarding the amplitude of lateral displacement of the head (ALH), treatments T1, $\mathrm{T} 2, \mathrm{~T} 3$ and $\mathrm{T} 4$ presented the highest values, not differing significantly from each other $(p<0.05)$; in the other treatments (Fig. 3D), these values were also larger than those obtained in the control $(1.14 \mu \mathrm{m})$. For the beat cross frequency (BCF), T1, T5, T6, T7 and T8 presented the highest values, without differing significantly from each other $(p<0.05)$. It is important to highlight that these values were also higher than the value found in the control $(7.0 \mathrm{~Hz})$, where $\mathrm{T} 4$ was the group that provided the lowest value for BCF (Fig. 3E).

Semen post-thawing motility. After the thawing of A. lacustris semen, no mobile sperm were observed in any of the treatments tested.

DNA integrity. DNA integrity analysis showed that, in terms of possible DNA degradation, there was no difference between the control and T1, T3, T5 and T6 treatments, but the $\mathrm{T} 5$ treatment was responsible for presenting a lower DNA damage index (ID) $(51 \pm 34.5)$ (Fig. 4). The highest IDs were found in treatments T7 and T8, showing lower DNA protection compared to other treatments.

For the T4 treatment, compaction of the sperm nucleus was observed (Fig. 5). This compaction is possibly due to the chemical components of this treatment, which did not allow the exposure of nuclear DNA and, consequently, an evaluation of its damage.

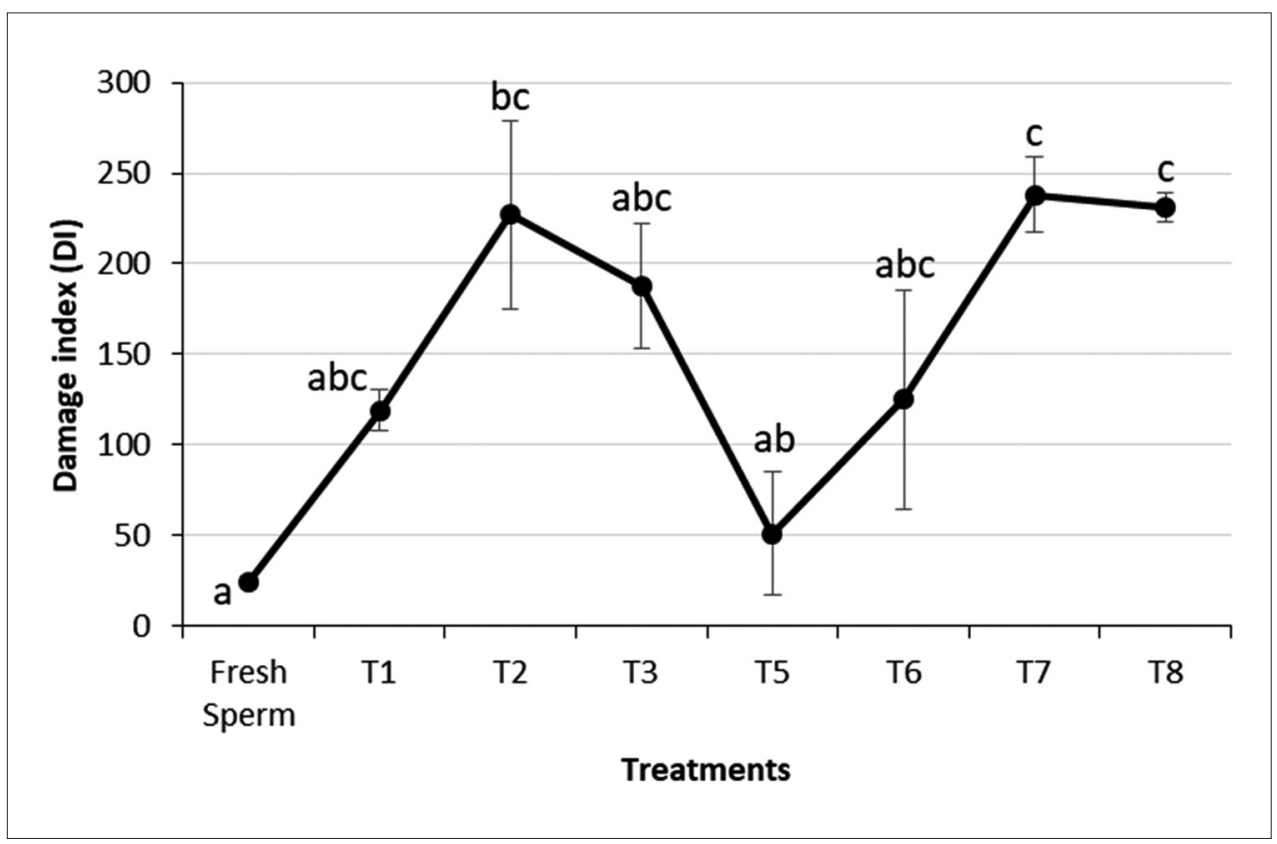

FIGURE 4 I Index of DNA damage generated by the cryopreservation process of Astyanax lacustris semen. Control - fresh semen, $\mathrm{T} 1-10 \%$ egg yolk $+5 \%$ glucose $+\mathrm{Me}_{2} \mathrm{SO} 10 \%$, T2 - 10\% egg yolk $+5 \%$ glucose $+\mathrm{Me}_{2} \mathrm{SO} 15 \%$, T3 $-10 \%$ egg yolk $+5 \%$ glucose + MTG010\%, T5 - BTS5\% $+\mathrm{Me}_{2} \mathrm{SO} 10 \%$, T6 - BTS5\% + $\mathrm{Me}_{2} \mathrm{SO} 15 \%$, T7 - 5\% Glucose $+\mathrm{Me}_{2} \mathrm{SO} 10 \%$ and T8 - 5\% Glucose + $\mathrm{Me}_{2} \mathrm{SO} 15 \%$. Different letters indicate significant differences $(\mathrm{p}<0.05)$ by the Kruskal-Wallis test. 


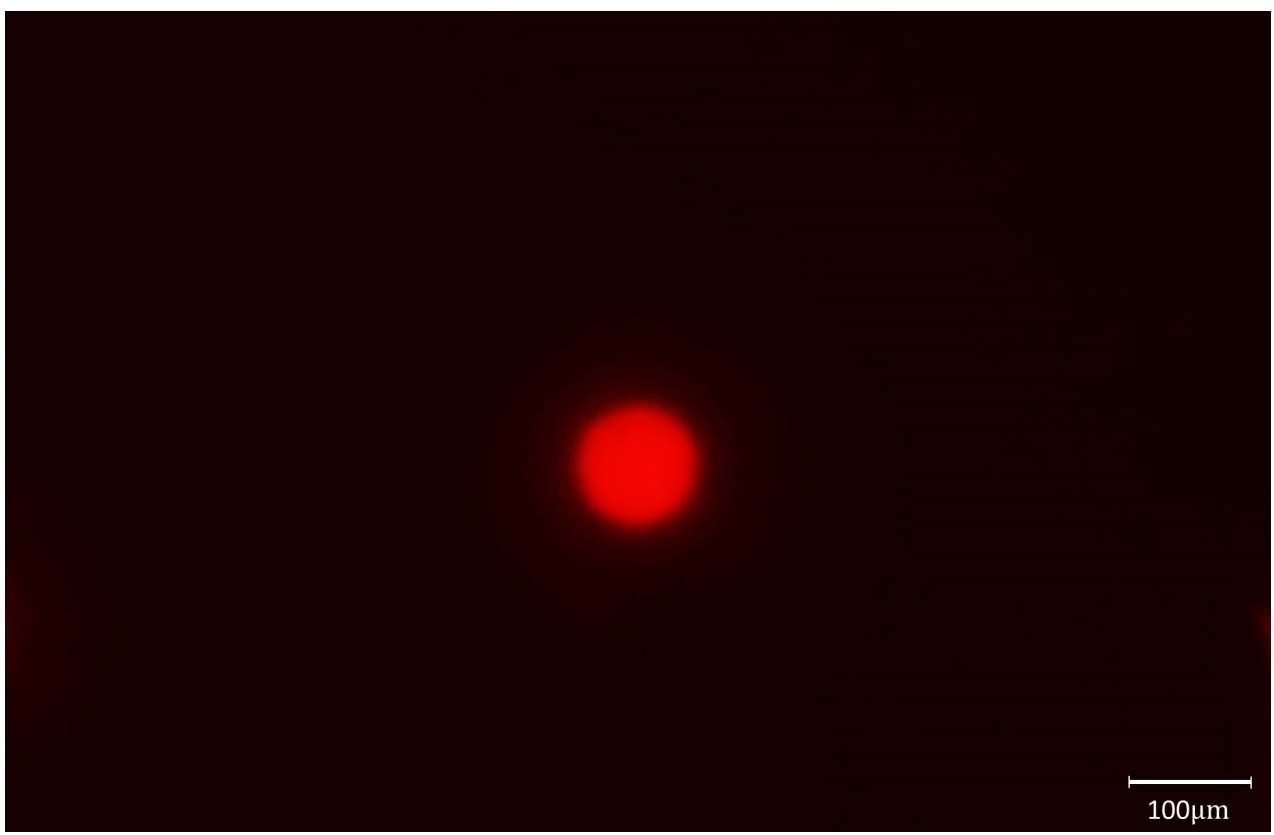

FIGURE 5 I Compressed cell nucleus found in T4 of cryopreservation process of Astyanax lacustris semen.

\section{DISCUSSION}

The seminal characteristics of the species are of great importance for assessing the quality of the breeders. In this study, the total motility of the fresh semen was low when compared to other species of Characiformes (Chiacchio et al., 2017; Paula et al., 2019) and the spermatozoa proved to be slower since the A. lacustris spermatozoa showed VCL values $(51.1 \mu \mathrm{m} / \mathrm{s})$ VSL $(41.4 \mu \mathrm{m} / \mathrm{s})$ and VAP $(48.2 \mu \mathrm{m} / \mathrm{s})$ lower than those of other Characiforms, such as Colossoma macropomum (VCL - $111.5 \mu \mathrm{m} / \mathrm{s}$; VSL - $77.2 \mu \mathrm{m} / \mathrm{s}$; VAP - 100, $6 \mu \mathrm{m} / \mathrm{s}$ ), Prochilodus brevis Steindachner, 1875 (VCL - $108.2 \mu \mathrm{m} \mathrm{s}$; VSL $45.8 \mu \mathrm{m} / \mathrm{s}$; VAP - $84.4 \mu \mathrm{m} / \mathrm{s}$ ), Brycon henni Eigenmann, 1913 (VCL - $115.4 \mu \mathrm{m} / \mathrm{s}$; VSL $64.8 \mu \mathrm{m} / \mathrm{s}$; VAP - $84.0 \mu \mathrm{m} / \mathrm{s}$ ) and Prochilodus lineatus (VCL - $245 \mu \mathrm{m} / \mathrm{s}$; VSL - $127 \mu \mathrm{m} / \mathrm{s}$; VAP - $204 \mu \mathrm{m} / \mathrm{s}$ ), which demonstrates the specificity of each species (Lopes et al., 2014; Pineda-Santis et al., 2015; Viveiros et al., 2017; Lopes et al., 2018).

The effectiveness of the sperm cryopreservation process is dependent on a number of factors such as sperm quality, diluents, cryoprotectants, dilution, and freezing and thawing velocity (Butts et al., 2010), all of which influence sperm motility.

Permeable cryoprotectants used in sperm freezing require low toxicity, small molecules, low molecular weight and high solubility (Chao, Liao, 2001) to reduce freezing points and cause cell dehydration, thus minimizing the cell formation of ice crystals. These substances are combined with non-permeable cryoprotectants which are large molecules that aid in cell dehydration, protect the plasma membrane and assist in osmotic homeostasis (Watson, 1995).

In the present study, the cryoprotectant toxicity test showed that the cryoprotectant solution composed of $\mathrm{Me}_{2} \mathrm{SO} 10 \%+$ glucose $5 \%$ best met these characteristics, presenting 
the highest values for total (MOT) and progressive (PRG) motility of spermatozoa of A. lacustris, as well as a greater amount of fast sperm. The higher PRG obtained with this extender is an important factor, since this parameter has a high correlation with the fertilization rate (Gallego, Asturiano, 2017).

The major protection that uses this combination of cryoprotectants has been related to the species Salminus brasiliensis (Cuvier, 1816) (Viveiros et al., 2009) and Epinephelus akaara (Temminck, Schlegel, 1843) (Ahn et al., 2018). In addition, the use of $\mathrm{Me}_{2} \mathrm{SO}$ with other diluents (Carolsfeld et al., 2003; Ninhaus-Silveira et al., 2006b; Tiba et al., 2009; Andrade et al., 2014; Fabbrocini et al., 2015; Shaliutina-Kolešová et al., 2019) is considered the most used cryoprotectant for freezing fish (Elliott et al., 2017).

The effectiveness of $\mathrm{Me}_{2} \mathrm{SO}$ is attributed to its low molecular weight and ability to easily bind to sperm membrane components, such as lipids and proteins, allowing molecular membrane reorganization after thawing (Pereira et al., 2019). Also, regarding total and progressive motility, the use of 5\% BTS with methyl glycol, regardless of concentration, was toxic to $A$. lacustris sperm, causing mortality after dilution. Viveiros et al. (2009) found that the use of this cryoprotective solution caused a reduction in sperm motility in Salminus brasiliensis from $85 \%$ to $60 \%$ after dilution, and that a total loss of sperm motility was found after thawing.

However, despite this result, other studies with Characiformes such as Brycon nattereri Günther, 1864 (Oliveira et al., 2007), Brycon insignis Steindachner, 1877 (Viveiros et al., 2011), and Brycon orbignyanus (Viveiros et al., 2015) have shown that the use of BTS ${ }^{\circledR}$ combined with methyl glycol was beneficial, with results superior or equal to the other solutions. In addition to these species, this freezing medium has also been tested for Steindachneridion scriptum (Miranda Ribeiro, 1918) siluriform (Pereira et al., 2019) and has also been positive, which further confirms the idea that cryoprotective solutions tend to be species-specific.

The toxicity caused by the cryoprotectant solution $\mathrm{BTS}^{\circledR}+$ methyl glycol also shows that there is an interaction between permeable and impermeable cryoprotectants, since the use of $\mathrm{BTS}^{\circledR}+\mathrm{Me}_{2} \mathrm{SO}$ (T5 and T6) did not cause total loss of motility, and the use of methyl glycol + yolk + glucose (T4) resulted in the second highest total motility (61\%) obtained in this study. For Brycon nattereri and Piaractus brachypomus (Cuvier, 1818), semen, an interaction between $\mathrm{Me}_{2} \mathrm{SO}$ and methyl glycol cryoprotectants with BTS ${ }^{\circledR}$ and Saad, $154 \mathrm{mM} \mathrm{NaCl}, 200 \mathrm{mM} \mathrm{NaCl}$ and $277 \mathrm{mM}$ glucose dilutors was also observed (Oliveira et al., 2007; Nascimento et al., 2010).

The analysis of fast, medium and slow sperm revealed that there was a negative effect of cryoprotective solutions on these aspects, characterized by an increase in medium and slow sperm, possibly this increase occurred due to the sensitivity of sperm to cryoprotectants (Chao and Liao, 2001) or as an effect of energy loss by the cell, which has a significant effect on semen quality and motility after thawing (Bondarenko et al., 2013; Figueroa et al., 2013).

The velocity values (VCL, VSL and VAP) were higher for T7 $\left(\mathrm{Me}_{2} \mathrm{SO} 10 \%+5 \%\right.$ glucose) and $\mathrm{T} 8\left(\mathrm{Me}_{2} \mathrm{SO} 15 \%+5 \%\right.$ glucose) sperm, which clearly indicates that these extenders provide higher sperm quality when compared with the other extenders used in this work. Sperm velocity is also an indicator of semen quality (Król et al., 2018), and these velocities are correlated with fertilization (Gallego et al., 2013). VCL is one of the parameters that is most closely related to fertilization capacity, as sperm with more 
circular motions are theoretically easier to find the micropile (Leite et al., 2018).

In addition, a higher curvilinear velocity is also considered to be characteristic of spermatozoa with faster trajectories, while higher VSL means that the sperm trajectory is more linear and regular, with less lateral movements, which would indicate the sperm's ability to move in a straight line (Chiacchio et al., 2017). For some treatments, LIN, STR and WOB values were not affected by extender dilution, and an increase in these parameters after dilution has already been reported for other species after freezing, such as Acipenser baerii Brandt, 1869 and Acipenser ruthenus Linnaeus, 1758 (Sieczyński et al., 2015).

Unlike studies already performed with other fish species (Cejko et al., 2012, 2013) that associate higher ALH values with higher VCL values, our study showed an opposite behavior, in which higher ALH values were found in treatments with lower VCL. According to Cejko et al. (2012), high ALH and BCF values would indicate better sperm quality, since high ALH values indicate sperm maturity (Cejko et al., 2018; Król et al., 2018).

After semen thawing, no sperm motility was observed for any of the treatments. Among the factors considered for this result, we can point out the low percentage of average total sperm motility (76.6\%) and the low amount of fast sperm (46.0\%); the published studies for species of the same order have a 90-100\% total motility for fresh semen (Lopes et al., 2014, 2018; Chiacchio et al., 2017; Paula et al., 2019).

Animals were provided with a balanced feed and disposition in a controlled environment ( $\mathrm{pH}, \mathrm{O}_{2}, \mathrm{~T}^{\circ} \mathrm{C}$, Conductivity, ammonia) during the experiment, without sudden changes that could affect sperm quality. In addition, during collections, all recommended measures to maintain sperm quality were taken, such as prior sedation, avoiding contamination with urine, feces or blood, and avoiding the early activation of sperm. As there are no data in the scientific literature regarding seminal characteristics for the species or for specimens of the genus Astyanax, it did not allow a comparison to determine whether these motility characteristics are inherent of this genus or species.

In addition, the amount of fast sperm decreased significantly in the diluted semen, which probably contributed to the loss of motility after freezing and thawing, since this decrease can be attributed to the loss of cell energy due to damage to mitochondria, thus limiting movement sperm. Several studies have shown that sperm viability is directly affected by damage to mitochondria and consequent loss of cellular energy (Liu et al., 2007; Bondarenko et al., 2013; Figueroa et al., 2013; Zilli et al., 2014; Yusoff et al., 2018).

Other factors are mentioned in the literature as possible causes of loss of motility after freezing, such as the freezing rate used which is conditioned by the volume and height of the nitrogen straws and the amount of straws by freezing because the species-specific freezing rate and affects sperm survival after thawing (Chao, Liao, 2001; NinhausSilveira et al., 2006b; Butts et al., 2010).

Although the thawed semen does not show motility, the DNA integrity test demonstrated that the use of these cryoprotective solutions were effective in maintaining the DNA integrity of the sperm cell. And the treatment composed of BTS and DMSO (T5) had the lowest ID (Damage Index) among all treatments, a fact also observed for treatments T1, T3 and T6 that also had low ID. For Steindachneridion scriptum, the use of this extender also resulted in low DNA fragmentation (0.051\%). BTS ${ }^{\circledR}+\mathrm{Me}_{2} \mathrm{SO}$ 
was also used in Prochilodus lineatus freezing but there was DNA fragmentation for all treatments analyzed in the study of Paula et al. (2019), unlike in our work, which demonstrates the influence of the species as well as the freezing method used, as the protocol applied in this study was different.

The use of a simple extender composed of glucose and $\mathrm{ME}_{2} \mathrm{SO}$ resulted in higher DNA fragmentation (T7 and T8), showing that this extender presented lower DNA protection efficiency. Nevertheless, the use of this extender for Salmo salar Linnaeus, 1758 was beneficial, generating low DNA fragmentation of only $4.8 \pm 2.58 \%$ (Figueroa et al., 2016). DNA fragmentation due to the cryopreservation process using the same $\mathrm{Me}_{2} \mathrm{SO}$ cryoprotectant has been reported for several species such as Dicentrarchus labrax (Linnaeus, 1758) (Zilli et al., 2003), rainbow trout (Oncorhynchus mykiss (Walbaum, 1792)) (Cabrita et al., 2005) and Prochilodus magdalenae Steindachner, 1879 (Martínez et al., 2012); however, the thinners used for these species differ from those used in our study.

There is some controversy as to the effect of such DNA damage on fertilization success. It is known that the beginning of embryonic development is controlled only by inherited maternal information (Zilli et al., 2003). Thus, the effects of DNA fragmentation would not be manifested at this stage. In addition, DNA damage can be repaired by the genetic repair mechanism during early embryogenesis (Cabrita et al., 2005), without affecting offspring quality. This was found for rainbow trout where, although the cryopreservation process induces increased sperm DNA fragmentation, such damage did not affect the survival or quality of the offspring (Labbe et al., 2001).

However, some studies show that DNA damage affects both fertilization and offspring quality. Pérez-Cerezales et al. (2011) found that the use of cryopreserved trout sperm with damaged DNA for fertilization caused an increase in telomere length, as well as causing alterations in gene expression in surviving embryos and larvae, thereby negatively affecting offspring development. For goldfish semen, there was a relationship between fertilization and DNA damage, where treatment with higher DNA fragmentation was responsible for the lowest fertilization rate (Nathanailides et al., 2011).

DNA integrity analysis also showed that only the treatment consisting of $5 \%$ glucose $+10 \%$ egg yolk $+15 \%$ methyl glycol (T4) contained highly compacted nuclei, indicating that there was no cell lysis, which consequently prevented the analysis of this treatment for DNA damage caused by the cryopreservation process. This compaction is the result of a chemical reaction caused by the increased concentration of methyl glycol.

In conclusion, in the present study, the toxicity test showed that the use of $5 \%$ glucose and $10 \% \mathrm{Me}_{2} \mathrm{SO}$ resulted in better maintenance of motility, progressivity and sperm speeds in A. lacustris semen. It is emphasized that there is a great sensitivity of the spermatozoa to methyl glycol combined with BTS and glucose. In addition, the cryoprotective solutions used did not lead to DNA fragmentation, thus maintaining the genetic integrity of $A$. lacustris sperm. However, A. lacustris sperm did not support the freezing protocol tested in this study, losing sperm viability and the ability to fertilize after thawing. Further studies are necessary to determine an effective protocol for cryopreservation the species semen. 


\section{ACKNOWLEDGMENTS}

The authors would like to thank the Fundação de Amparo à Pesquisa do Estado de São Paulo (FAPESP) for the financial support for this research (Fapesp Process \# 2015 / 10115-5), and the Fundação de Amparo à Pesquisa e ao Desenvolvimento Científico e Tecnológico do Maranhão - FAPEMA for their scholarship granted (Edital Fapema $\mathrm{n}^{\mathrm{o}}$ 045/2017 - Master in the country) and the Neotropical Ichthyology Laboratory and Molecular Genetics and Applied Statistics Laboratory of the State University of São Paulo "Júlio de Mesquita Filho" for technical and scientific support.

\section{REFERENCES}

- Ahn JY, Park JY, Lim HK. Effects of different diluents, cryoprotective agents, and freezing rates on sperm cryopreservation in Epinephelus akaara. Cryobiology. 2018; 83:60-64. https://doi. org/10.1016/j.cryobiol.2018.06.003

- Andrade ES, Paula DAJ, Felizardo VO, Murgas LDS, Veras GC, Rosa PV. Milt cryopreservation for rheophilic fish threatened by extinction in the Rio Grande, Brazil. CryoLetters. 2014; 35(1):8-14. Available from: https:// www.ingentaconnect.com/content/ cryo/cryo/2014/00000035/00000001/ art00002?crawler=true

- Bashiyo-Silva C. Indução a espermiação e criopreservação espermática de Brycon cephalus (Gunther, 1869) (Teleostei: Characidae). [Masters Thesis]. Ilha Solteira: Faculdade de Engenharia, Universidade Estadual Paulista "Júlio de Mesquita Filho"; 2014. Available from: https://repositorio. unesp.br/handle/11449/115995

- Bondarenko O, Dzyuba B, Cosson J, Yamaner G, Prokopchuk G, Psenicka M. Volume changes during the motility period of fish spermatozoa: interspecific differences. Theriogenology. 2013; 79(5):872-81. https://doi.org/10.1016/j. theriogenology.2013.01.005

- Butts IAE, Litvak MK, Kaspar V, Trippel EA. Cryopreservation of Atlantic cod Gadus morhua L. spermatozoa: Effects of extender composition and freezing rate on sperm motility, velocity and morphology. Cryobiology. 2010; 61(2):174-81. https://doi. org/10.1016/j.cryobiol.2010.07.001
- Cabrita E, Robles V, Rebordinos L, Sarasquete C, Herráez MP. Evaluation of DNA damage in rainbow trout (Oncorhynchus mykiss) and gilthead sea bream (Sparus aurata) cryopreserved sperm. Cryobiology. 2005; 50(2):144-53. https://doi.org/10.1016/j. cryobiol.2004.12.003

- Carneiro PCF, Azevedo HC, Santos PS, Maria AN. Cryopreservation of tambaqui (Colossoma macropomum) semen: extenders, cryoprotectants, dilution ratios and freezing methods. CryoLetters. 2012; 33(5):385-93. Available from: https:// europepmc.org/article/med/23224371

- Carolsfeld J, Godinho HP, Zaniboni-Filho E, Harvey BJ. Cryopreservation of sperm in Brazilian migratory fish conservation. J Fish Biol. 2003; 63(2):472-89. https://doi. org/10.1046/j.1095-8649.2003.00170.x

- Cárton-Garcia F, Riesco MF, Cabrita E, Herráez MP, Robles V. Quantification of lesions in nuclear and mitochondrial genes of Sparus aurata cryopreserved sperm. Aquaculture. 2013; 402-403:106-12. https:// doi.org/10.1016/j.aquaculture.2013.03.034

- Cejko BI, Horváth A, Kollár T, Kása E, Lujić J, Marinović Z, Urbányi B, Kowalski RK. Optimisation of sodium and potassium concentrations and $\mathrm{pH}$ in the artificial seminal plasma of common carp Cyprinus carpio L. Fish Physiol Biochem. 2018; 44:1435-42. https://doi.org/10.1007/s10695018-0491-3

- Cejko BI, Sarosiek B, Kowalski RK, Krejszeff S, Kucharczyk D. Application of Computer-assisted Sperm Analysis in selecting the suitable solution for Common Carp, Cyprinus carpio L. sperm motility. J World Aquac Soc. 2013; 44(3):466-72. https://doi.org/10.1111/jwas.12043 
- Cejko BI, Targońska K, Kowalski RK, Żarski D, Sarosiek B, Kucharczyk D, Glogowski J. The effectiveness of hormonal preparations (Ovopel, Ovaprim, LHRHa, hCG and CPE) in stimulating spermiation in dace Leuciscus leuciscus (L.). J Appl Ichthyol. 2012; 28(6):873-77. https://doi.org/10.1111/jai.12054

- Chao NH, Liao IC. Cryopreservation of finfish and shellfish gametes and embryos. Aquaculture. 2001; 197(1-4):161-89. https:// doi.org/10.1016/S0044-8486(01)00586-5

- Chiacchio IMD, Almeida ILG, Leal MC, Viveiros ATM. Sperm quality and its freezing ability throughout the spawning season in Prochilodus lineatus and Brycon orbignyanus. Theriogenology. 2017; 90:284-88. https://doi.org/10.1016/j. theriogenology.2016.12.011

- Ciereszko A, Dietrich GJ, Nynca J, Dobosz S, Zalewski T. Cryopreservation of rainbow trout semen using a glucosemethanol extender. Aquaculture. 2014; 420-421:275-81. https://doi.org/10.1016/j. aquaculture.2013.11.014

- Elliott GD, Wang S, Fuller BJ. Cryoprotectants: A review of the actions and applications of cryoprotective solutes that modulate cell recovery from ultra-low temperatures. Cryobiology. 2017; 76:74-91. https://doi.org/10.1016/j. cryobiol.2017.04.004

- Fabbrocini BA, D’Adamo R, Pelosi S, Oliveira LFJ, Del-Prete F, Silvestri F, Vitiello V, Sansone G. Sperm motility evaluation following long-term storage (5 years) of cryopreserved sea bream (Sparus aurata L., 1758) semen. J Appl Ichthyol. 2015; 31(S1):104-07. https://doi.org/10.1111/ jai.12726

- Figueroa E, Risopatrón J, Sánchez R, Isachenko E, Merino O, Valdebenito I. Sperm vitrification of sex-reversed rainbow trout (Oncorhynchus mykiss): effect of seminal plasma on physiological parameters. Aquaculture. 2013; 372375:119-26. https://doi.org/10.1016/j. aquaculture.2012.10.019

- Figueroa E, Valdebenito I, Merino O, Ubilla A, Risopatrón J, Farias JG. Cryopreservation of Atlantic Salmon Salmo salar sperm: effects on sperm physiology. J Fish Biol. 2016; 89(3):1537-50. https://doi. org/10.1111/jfb.13052
- Gallego V, Asturiano JF. Sperm motility in fish: technical applications and perspectives through CASA-Mot systems. Reprod Fertil Dev. 2017; 30(6):820-32. https://doi.org/10.1071/RD17460

- Gallego V, Pérez L, Asturiano JF, Yoshida M. Relationship between spermatozoamotility parameters, sperm/egg ratio, and fertilization and hatching rates in pufferfish (Takifugu niphobles). Aquaculture. 2013; 416417:238-243. https://doi.org/10.1016/j. aquaculture.2013.08.035

- Galo JM, Streit Jr. DP, Oliveira CA, Povh JP, Fornari DC, Digmayer M, Ribeiro RP. Quality of fresh and cryopreserved semen and their influence on the rates of fertilization, hatching and quality of the larvae of Piaractus mesopotamicus. Braz J Biol. 2019; 79(3):438-45. https://doi. org/10.1590/1519-6984.182391

- Gonçalves LU, Ferroli F, Viegas EMM. Effect of the inclusion of fish residue oils in diets on the fatty acid profile of muscles of males and females lambari (Astyanax altiparanae). Rev Bras Zootec. 2012b; 41(9):1967-74. https://doi.org/10.1590/ S1516-35982012000900001

- Gonçalves LU, Parisi G, Bonelli A, Sussel FR, Viegas EMM. The fatty acid compositions of total, neutral and polar lipids in wild and farmed lambari (Astyanax altiparanae) (Garutti \& Britski, 2000) broodstock. Aquac Res. 2012a; 45(2):195-203. https://doi.org/10.1111/ j.1365-2109.2012.03215.x

- Judycka S, Nynca J, Liszewska E, Dobosz S, Zalewski T, Cieresko A. Optimal sperm concentration in straws and final glucose concentration in extender are crucial for improving the cryopreservation protocol of salmonid spermatozoa. Aquaculture. 2018; 486:90-97. https://doi.org/10.1016/j. aquaculture.2017.12.019

- Klaude M, Eriksson S, Nygren J, Ahnström G. The comet assay: mechanisms and technical considerations. DNA Repair. 1996; 363(2):89-96. https://doi. org/10.1016/0921-8777(95)00063-1

- Kobayashi H, Sugiyama C, Morikawa Y, Hayashi M, Sofuni T. A comparison between manual microscopic analysis and computerized image analysis in the single cell gel electrophoresis assay. MMS Commun. 1995; 3:103-15. Available from: https://www.scienceopen.com/ document?vid=3c9a53e6-a18e-49ae-865511b6acd50b63 
- Król J, Żarski D, Bernáth G, PalińskaŻarska K, Krejszeff S, Długoński A, Horváth A. Effect of urine contamination on semen quality variables in Eurasian perch Perca fluviatilis L. Anim Reprod Sci. 2018; 197:240-46. https://doi.org/10.1016/j. anireprosci.2018.08.034

- Labbe C, Martoriati A, Devaux A, Maisse G. Effect of sperm cryopreservation on sperm DNA stability and progeny development in rainbow trout. Mol Reprod Dev. 2001; 60(3):397-404. https://doi. org/10.1002/mrd.1102

- Leite JS, Oliveira-Araújo MS, AlmeidaMonteiro PS, Campello CC, Campos ACN, Salmito-Vanderley CSB. Seasonal variation in seminal quality in Brazilian bocachico (Teleostei, Characiformes). Rev Caatinga. 2018; 31(3):759-66. http://dx.doi. org/10.1590/1983-21252018v31n326rc

- Liu QH, Li J, Zhang SC, Xiao Z.Z, Ding FH, Yu DD, Xu XZ. Flow cytometry and ultrastructure of cryopreserved red seabream (Pagrus major) sperm. Theriogenology. 2007; 67(6):1168-74. https://doi.org/10.1016/j. theriogenology.2006.12.013

- Lopes JT, Oliveira-Araújo MS, Nascimento RV, Ferreira YM, Montenegro AT, Salmito-Vanderley CSB. Efeito de vitaminas e aminoácidos como suplementação da solução crioprotetora para a criopreservação do sêmen de tambaqui (Colossoma macropomum). Acta Sci Vet. 2018; 46:1593-600. Available from: https://pesquisa.bvsalud.org/portal/ resource/pt/vti-18361

- Lopes JT, Pinheiro JPS, Nunes LT, Pinheiro RRR, Souza MEM, Almeida PS, Nascimento RV, Campello CC, SalmitoVanderley CSB. Avaliação de diferentes crioprotetores e taxas de diluição na criopreservação seminal de Prochilodus brevis. Rev Bras Reprod Anim. 2014; 38(3):170-75. Available from: https://www. researchgate.net/publication/273632075_ Avaliacao_de_diferentes_crioprotetores_e_ taxas_de_diluicao_na_criopreservacao_ seminal_de_Prochilodus_brevis

- Lucena CAS, Soares HG. Review of species of the Astyanax bimaculatus "caudal peduncle spot” subgroup sensu Garutti \& Langeani (Characiformes, Characidae) from the rio La Plata and rio São Francisco drainages and coastal systems of southern Brazil and Uruguay. Zootaxa. 2016; 4072(1):101-25. https://doi.org/10.11646/ zootaxa.4072.1.5
- Maria AN, Viveiros ATM, Freitas RTF, Oliveira AV. Extenders and cryoprotectants for cooling and freezing of piracanjuba (Brycon orbignyanus) semen, an endangered Brazilian teleost fish. Aquaculture. 2006; 260(14):298-306. https://doi.org/10.1016/j. aquaculture.2006.06.011

- Martínez JG, García VA, Carrasco SP. DNA fragmentation and membrane damage of bocachico Prochilodus magdalenae (Ostariophysi: Prochilodontidae) sperm following cryopreservation with dimethyl sulfoxide and glucose. Neotrop Ichthyol. 2012; 10(3):577-86. http://dx.doi.org/10.1590/ S1679-62252012005000018

- Nascimento AF, Maria AN, Pessoa NO, Carvalho MAM, Viveiros ATM. Out-ofseason sperm cryopreserved in different media of the Amazonian freshwater fish pirapitinga (Piaractus brachypomus). Anim Reprod Sci. 2010; 118(2-4):324-29. https:// doi.org/10.1016/j.anireprosci.2009.07.002

- Nathanailides C, Chanzaropoulos T, Barbouti A, Perdikaris C, Zhang T. DNA fragmentation, linear velocity and fertilizing ability of reactivated cryopreserved goldfish sperm using different cryoprotectants. Biotechnology. 2011; 10(6):514-20. https://doi.org/10.3923/ biotech.2011.514.520

- Ninhaus-Silveira A, Foresti F, VeríssimoSilveira R, Senhorini JA. Seminal analysis, cryogenic preservation, and fertility in matrinxã fish, Brycon cephalus (Günther,1869). Braz Arch Biolol Techn. 2006b; 49(4):651-59. http://dx.doi. org/10.1590/S1516-89132006000500015

- Ninhaus-Silveira A, Veríssimo-Silveira R, Senhorini JA, Alexandre JS, Chaguri MP. Fertilidade do sêmen de matrinxã (Brycon amazonicus) criopreservado em nitrogênio líquido. Bol Tec CEPTA. 2006a; 19:1-8. Available from: https://biblat. unam.mx/pt/revista/boletim-tecnico-docepta/articulo

- Oliveira AV, Viveiros ATM, Maria AN, Freitas RTF, Izaú ZA. Sucesso do resfriamento e congelamento de sêmen de pirapitinga Brycon nattereri. Arq Bras Med Vet Zootec. 2007; 59(6):150915. https://doi.org/10.1590/S010209352007000600025 
- Paula DAJ, Murgas LDS, Castro TFD, Assis IL, Neto RVR, Marcussi S. Effects of cooling rates on the quality of Prochilodus lineatus (Valenciennes, 1836) sperm. Reprod Domest Anim. 2019; 54(7):1034-43. https://doi. org/10.1111/rda.13459

- Pereira JR, Pereira FA, Perry CT, Pires DM, Muelbert JRE, Garcia JRE, Corcini CD, Varela-Junior AS. Dimethyl sulfoxide, methanol and methyl glycol in the seminal cryopreservation of Suruvi, Steindachneridion scriptum. Anim Reprod Sci. 2019; 200:7-13. https://doi.org/10.1016/j. anireprosci.2018.09.024

- Pérez-Cerezales S, Gutiérrez-Adán A, Martínez-Páramo S, Beirão J, Herráez MP. Altered gene transcription and telomere length in trout embryo and larvae obtained with DNA cryodamaged sperm. Theriogenology. 2011;

76(7):1234-45. https://doi.org/10.1016/j. theriogenology.2011.05.028

- Pineda-Santis H, Gómez-Oquendo J, Montoya-Páez J, Toro-Rendón V, Acevedo-Villa 0, Restrepo-Betancur G. Crioconservación de semen y calidad espermática en sabaleta Brycon henni (Pisces: Characidae). Rev Orinoquia. 2015; 19(2):166-73. Available from: https://www. redalyc.org/articulo.oa?id=89645829003

- RStudio Team (2015). RStudio: Integrated Development for R. RStudio, Inc., Boston, MA URL http://www.rstudio.com/

- Sabbag OJ, Takahashi LS, Silveira NA, Aranha AS. Custos e viabilidade econômica da produção de lambari-do-rabo amarelo em Monte Castelo/ SP: um estudo de caso. Bol Inst Pesca. 2011; 37(3):307-15. Available from: https://www.pesca.sp.gov. br/37_3_307-315.pdf

- Shaliutina-Kolešová A, Dietrich M, Xian M, Nian N. Seminal plasma transferrin effects on cryopreserved common carp Cyprinus carpio sperm and comparison with bovine serum albumin and antifreeze proteins. Anim Reprod Sci. 2019; 204:125-30. https://doi.org/10.1016/j. anireprosci.2019.03.013

- Sieczyński P, Cejko BI, Grygoruk C, Glogowski J. Cryopreservation of Siberian sturgeon (Acipenser baerii, Brandt, 1869) and sterlet (Acipenser ruthenus, Linnaeus, 1758) semen and its influence on sperm motility parameters assessed using a computer-assisted sperm analysis (CASA) system. J Appl Ichthyol. 2015; 31(S1):99-103. https://doi.org/10.1111/jai.12719
- Singh NP, McCoy MT, Tice RR, Schneider EL. A simple technique for quantitation of low-levels of DNA damage in individual cells. Exp Cell Res. 1988; 175(1):184-91. Available from: https://doi. org/10.1016/0014-4827(88)90265-0

- Streit Jr. DP, Benites C, Moraes GV, Ribeiro RP, Sakaguti ES, Caldieri RF. Sêmen de pacu (Piaractus mesopotamicus) criopreservado com diluentes utilizados para sêmen de suínos. Ciênc Anim Bras. 2006; 7:289-97. Available from: https:// www.revistas.ufg.br/vet/article/view/409

- Tiba RM, Oliveira IR, Serralheiro PCS, Ostini S. Diluentes e proporções sêmen: diluente na crioconservação do sêmen de robalo-peva Centropomus parallelus. Bol Inst Pesca. 2009; 35(1):99-110. Available from: ftp://ftp.sp.gov.br/ ftppesca/35_1_99-110.pdf

- Viveiros AMT, So N, Komen J. Sperm cryopreservation of African catfish Clarias gariepinus cryoprotectants, freezing rates and sperm: egg dilution ratio. Theriogenology. 2000; 54(9):1395408. https://doi.org/10.1016/S0093691X(00)00462-3

- Viveiros ATM, Amaral TB, Orfão LH, Isaú ZA, Caneppele D, Leal MC. Sperm cryopreservation of tiete tetra Brycon insignis (Characiformes): effects of cryoprotectants, extenders, thawing temperatures and activating agents on motility features. Aquac Res. 2011; 42(6):858-65. https://doi.org/10.1111/j.13652109.2010.02761.x

- Viveiros ATM, Di Chiacchio IM, Almeida ILG, Taffarel TR, Leal MC. Storage and transportation of Prochilodus lineatus (Characiformes) sperm prior to cryopreservation. Gen Comp Endocrinol. 2017; 245:84-88. https://doi.org/10.1016/j. ygcen.2016.08.005

- Viveiros ATM, Orfão LH, Nascimento AF, Corrêa FM, Caneppele D. Effects of extenders, cryoprotectants and freezing methods on sperm quality of the threatened Brazilian freshwater fish pirapitinga-do-sul Brycon opalinus (Characiformes). Theriogenology. 2012; 78(2):361-68. https://doi.org/10.1016/j. theriogenology.2012.02.015 
- Viveiros ATM, Nascimento AF, Orfão LH, Isaú ZA. Motility and fertility of the subtropical freshwater fish streaked prochilod (Prochilodus lineatus) sperm cryopreserved in powdered coconut water. Theriogenology. 2010; 74(4):551-56. https://doi.org/10.1016/j. theriogenology.2010.03.018

- Viveiros ATM, Nascimento AF, Leal MC, Gonçalves ACS, Orfão L, Cosson J. Methyl glycol, methanol and DMSO effects on post-thaw motility, velocities, membrane integrity and mitochondrial function of Brycon orbignyanys and Prochilodus lineatus (Characiformes) sperm. Fish Physiol Biochem. 2015; 41:193-201. https:// doi.org/10.1007/s10695-014-0016-7

- Viveiros ATM, Oliveira AV, Maria AN, Orfão LH, Souza JC. Sensibilidade dos espermatozoides de dourado (Salminus brasiliensis) a diferentes soluções crioprotetoras. Arq Bras Med Vet Zootec. 2009; 61(4):883-89. https://doi.org/10.1590/ S0102-09352009000400016

- Watson PF. Recent developments and concepts in the cryopreservation of spermatozoa and the assessment of their post-thawing function. Reprod Fertil Dev. 1995; 7(4):871-91. Available from: https:// www.publish.csiro.au/RD/RD9950871

- Yang H, Daly J, Carmichael C, Matthews J, Varga ZM, Tiersch T. A procedurespanning analysis of plasma membrane integrity for assessment of cell viability in sperm cryopreservation of zebrafish Danio rerio. Zebrafish. 2016; 13(2):144-51. https:// doi.org/10.1089/zeb.2015.1176
- Yasui GS, Senhorini JA, Shimoda E, Pereira-Santos M, Nakaghi LSO, Fujimoto T Arias-Rodriguez L, Silva LA. Improvement of gamete quality and its short-term storage: an approach for biotechnology in laboratory fish. Animal. 2015; 9(3):464-70. https://doi.org/10.1017/ S1751731114002511

- Yusoff M, Hassan BN, Ikhwanuddin M, Sheriff SM, Hashim F, Mustafa S, Koh ICC. Successful sperm cryopreservation of the brown-marbled grouper, Epinephelus fuscoguttatus using propylene glycol as cryoprotectant. Cryobiology. 2018; 81:168-73. https://doi.org/10.1016/j. cryobiol.2018.01.005

- Zanandrea ACV, Weingartner M, Zaniboni-Filho E. Induced reproduction of dourado (Salminus brasiliensis): fertilization with sperm cryopreserved in $\mathrm{ACP}^{\circledR}$-104. Acta Sci. 2016; 38(1):17-22. https://doi.org/10.4025/actascianimsci. v38i1.28838

- Zilli L, Beirão J, Schiavone R, Herraez MP, Gnoni A, Vilella S. Comparative proteome analysis of cryopreserved flagella and head plasma membrane proteins from sea bream spermatozoa: effect of antifreeze proteins. PLoS One. 2014; 9(6):e99992. https://doi.org/10.1371/ journal.pone.0099992

- Zilli L, Schiavone R, Zonno V, Storelli C, Vilella S. Evaluation of DNA damage in Dicentrarchus labrax sperm following cryopreservation. Cryobiology. 2003; 47(3):227-35. https://doi.org/10.1016/j. cryobiol.2003.10.002

\section{AUTHOR CONTRIBUTION @}

Laicia Carneiro-Leite: Conceptualization, Data curation, Formal analysis, Investigation, Methodology, Project administration, Resources, Supervision, Validation, Visualization, Writing-original draft, Writingreview \& editing.

Cristiane Bashiyo-Silva: Formal analysis, Methodology.

Yasmim Alves Araújo Oliveira: Formal analysis, Investigation, Methodology, Software.

Laís Pedroso Borges: Formal analysis, Methodology, Visualization.

Malbelys Padilla Sanchez: Data curation, Methodology.

Luciane Gomes da Silva: Formal analysis, Methodology, Software.

Stella Indira Rocha Lobato: Formal analysis, Methodology.

Flávia Cristina Rodrigues-Lisoni: Formal analysis, Methodology, Supervision, Writing-review \& editing. Rosicleire Veríssimo-Silveira: Investigation, Supervision, Writing-review \& editing.

Alexandre Ninhaus-Silveira: Conceptualization, Data curation, Formal analysis, Funding acquisition, Investigation, Methodology, Project administration, Resources Supervision, Visualization, Writing-review \& editing. 


\section{Neotropical lchthyology}

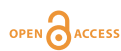

\section{(c) (1)}

This is an open access article under the terms of the Creative Commons Attribution License, which permits use, distribution and reproduction in any
provided the original work is properly cited.

Distributed under

Creative Commons CC-BY 4.0

๑) 2020 The Authors.

Diversity and Distributions Published by SBI

2 Official Journal of the

3 Sociedade Brasileira de Ictiologia

SBI

\section{ETHICAL STATEMENT}

All procedures were performed and approved by the Animal Use Ethics Committee - CEUA of the Engineering College, UNESP, Ilha Solteira Campus, Process CEUA-FEIS/UNESP 05/2017.

\section{COMPETING INTERESTS}

The authors declare no competing interests.

\section{HOW TO CITE THIS ARTICLE}

- Carneiro-Leite L, Bashiyo-Silva C, Oliveira YAA, Borges LP, Sanchez MP, Silva LG, Lobato SIR, Rodrigues-Lisoni FC, Veríssimo-Silveira R, Ninhaus-Silveira A. Seminal characteristics and sensitivity of Astyanax lacustris (Characiformes: Characidae) sperm to cryoprotective solutions based on dimethylsufoxide and methylglicol. Neotrop Ichthyol. 2020; 18(3):e200039. https://doi.org/10.1590/1982-0224-2020-0039 